\title{
Effect of Barrel temperature Feed composition and Feed moisture content on some Functional Properties of Dakuwa extrudates from Blends of Sorghum ((Sorghum bicolour L) Groundnut (Arachis hypogeal $L$ ) and Tiger nut (Cyperus esculentus)
}

\author{
M. Yusuf ${ }^{1}$, M. Halilu², I. Umar' ${ }^{2}$, K. B. Filli ${ }^{3}$ \\ 123 Department of Food Science and Technology Modibbo Adama University of Technology \\ Yola, PMB 2076 Yola, Nigeria. \\ ${ }^{3}$ Swedish Institute for Food and Biotechnology Gothenburg, Sweden. \\ Corresponding Author's E-mail: yusufmoh2015@yahoo.com
}

\begin{abstract}
Dakuwa is a traditional snack produced from blends of sorghum groundnut and tigernut. A three factor three level full factorial experimental design were adapted to determine the effect of extrusion on some functional properties of dakuwa extrudate using twin screw extruder (SLG 65-III Model). The effects of extrusion variables barrel temperature $\left(90^{\circ} \mathrm{C} 100^{\circ} \mathrm{C} 110^{\circ} \mathrm{C}\right)$ feed composition $(50: 20: 30$ 50:25:25 50:30:20 ratios of sorghum groundnut to tigernut), feed moisture content (18\% $22 \% 26 \%$ ) on the water absorption index (WAI); water solubility index (WSI); water hydration capacity (WHC) and viscosity from sorghum groundnut and tigernut raw mixtures and the extruded were studied extrusion significantly increased the water absorption index (WAI) from 2.05 to 2.17; water solubility index WSI from 4.49 to 9.14 and water hydration capacity WHC from 1.05 to 1.54 raw to extrudate while viscosity decreased from 11.60 to 8.33 mpas. The optimum levels of the variables were obtained. The optimal combination of barrel temperature of $90^{\circ} \mathrm{C}$ feed composition of (50:20:30 sorghum groundnut tigernut) and $18 \%$ feed moisture resulted in optimal WAl of $2.49 \mathrm{~g}$ Water perg Sample. The optimal combination of $110^{\circ} \mathrm{C}$ barrel temperature 50:30:20 feed composition for sorghum groundnut and tigernut and $22 \%$ feed moisture resulted in optimal WSI of $12.13 \%$. The optimal combination of $100^{\circ} \mathrm{C}$ barrel temperature $(50: 30: 20$ feed composition for sorghum groundnut and tigernut) and $26 \%$ feed moisture resulted in optimal WHC of $4.95 \%$. The optimal combination of $90^{\circ} \mathrm{C}$ barrel temperature $(50: 20: 30$ feed composition sorghum groundnut tigernut) and $18 \%$ feed moisture resulted in optimal viscosity of $9.23 \mathrm{mpa}$.
\end{abstract}

Keywords: Sorghum, groundnut, tigernut, extrusion, optimization, 'dakuwa', water absorption index, water solubility index, water hydration capacity, viscosity.

\section{INTRODUCTION}

Sorghum and maize are the most popular cereals consumed by adults and infants in Africa, south of the Sahara (Asiedu et al., 1993). Sorghum is a major source of protein and calories in the diets of large segment of the populations of Africa and Asia (Yousif and El Tinay, 2001). Sorghum is used to prepare various dishes in different parts of the world. It can be used in production of fermented and unfermented bread, stiff porridge, thin 
porridge, steamed c1ooked products, boiled whole or pearled, snack foods, alcoholic beverages, and nonalc1oholic beverages (Rooney and Serna-Saldivar, 1982). The sorghum flour is used to prep1ared local bread known as Khamir in Gizan province, Saudi Arabia (Gassem, 1999).

The sorghum grain quality is affected by factors such as gen1otype, climate, soil type, and fertiliza1tion, among others, which can affect the chemical composition and the nutritive value (E1badi et al., 2005). Starch is the main component of sorghum grain, followed by proteins, Non-Starch Polysaccharides [NSP] and fat Board on Science and Technology for International DevelopmentNational Research Council [BSTID- NRC] (1996). Its protein content is higher than that of corn although its nutritional protein quality is lower (Dowling et al., 2002). Moreover, high tannins content in sorghum bind to protein, carbohydrates, and minerals making these nutrients unavailable f1or digestion by the body. Reduction of the tannins levels is possible through decortications, fermentation, germination and chemical treatment (Beta et al., 1999, Dicko et al., 2005 and Drina et al., 1999).

Tiger nut is a tuber that is grown in the soil. It has a dimension ranging from 6-10 $\mathrm{mm}$ and occurs in different varieties. The colour is brown and has a sweet flavour when eaten. Tiger nut has been used extensively mainly for human consumption in Spain (Mason, 2008; Tiger nuts Traders, 2009). Tiger nuts are prepared and eaten cold as snacks. The milk can be extracted, treated and bottled. The flour is used to make cakes and biscuits and the oil is used for cooking (Wise, 2009). In United Kingdom, tiger nut is superb bait for carp fishing (Wise, 2009). In Nigeria, the utilization of tiger nut is highly limited in spite of the fact that tiger nut is cultivated widely in the Northern part of the country. Tiger nuts are eaten raw mainly as snacks or fried and eaten mixed with roasted groundnuts (Abaejoh et al., 2006). Kofi (1990) reported that sweetened tiger nut extract are bottled and sold in Ghana. Recently, there is awareness for increased utilization of tiger nut (Belewu and Abodurin, 2006; Belewu and Belewu, 2007; Ade-Omowaye et al., 2008; Ukwuru et al., 2008). Tiger nuts are valued for their highly nutritious starch content, dietary fibre and carbohydrate (Umene and Enebeli, 1997) and are rich in sucrose $(17.4-20.0 \%)$, fat $(25.5 \%)$, protein $(8.0 \%)$ (Kordyias, 1990; Temple et al., 1990). Tiger nut is also rich in mineral content such as sodium, calcium, potassium, magnesium, zinc and traces of copper (Omode et al., 1995; Oladele and1 Aina, 2007).

Groundnuts (Arachis hypogeal) or peanut is a legume which is widely grown as a food crop. It is an herbaceous plant of which there are different varieties such as Boro light, Boro Red, Mokwa, Campala, Guta and Ela (Anyasor, 2009). Peanut is an important source of edible oil for millions of people living in the tropics. In Nigeria, 1917 tons of peanuts are being produced annually (Ergul, 1988). Peanuts are among the oldest oil crops in Nigeria and are mostly consumed as Snack, after roasting (Bansal et al., 1993; jambunathan et al., 1993). Vegetable oil had made an important contribution to the diet in many countries, serving as a good source of protein, lipid and fatty acids for human nutrition including the repair of worn out tissue, new cells formation as well as a useful source of energy (Gaydon et al., 1983;Grosso and Guzman, 1995; Grosso et al., 1997,1999). Groundnut provides an inexpensive source of high quality dietary protein and oil. The vast food preparations incorporating groundnut to improve the protein level has helped in no small way in reducing malnutrit1ion in the developing Countries (Asibuo et al., 2008). Groundnut seed contains 44 to $56 \%$ oil and 22 to $30 \%$ protein on a dry seed basis and is a rich source of minerals $(\mathrm{P}, \mathrm{Ca}$, $\mathrm{Mg}$ and $\mathrm{K}$ ) and Vitamins (E, K and 11B group) (Savage and Keenan, 1994).

Dakuwa is a cereal and legume based snack item prominent throughout northern Nigeria. It consists basically of roasted tiger nut and roasted groundnut paste, while roasted sorghum flour is optional depending on cultural provision (Bagirei, 2005). Dakuwa is a cereal and groundnut based snack. It is mainly consumed in the northern parts of Nigeria. Dakuwa is prepared from mixtures of cereals, groundnut, ground pepper, ginger, sugar and salt. The ingredients are thoroughly mixed, pounded and molded into balls that can be eaten without further processing (Abdulrahman and Kolawole, 2003). Nkama and Gbenyi (2001) reported that dakuwa is also produced from cereals (maize, millet and sorghum), tiger nuts and groundnuts. These authors also reported that in the traditional method of dakuwa processing, the grains are cleaned, toasted and ground together to give a paste.

Extrusion technology is one of the contemporary food technologies applied to food (Happer and Jansen, 1985) and can be applied to mitigate the problems associated with processing of traditional cereal based products in terms of improvement in functionality, physical state and shelf stability. It offers many advantages over other process technologies in terms of preparation of ready-to-eat foods of desired shape, size, texture and sensory characteristics at relatively low processing cost (Sumathi et al., 2007). Extrusion is a powerful food Processing operation, which utilizes high temperature and high shear force to produce a Product with unique physical and chemical characteristics (Pansawat et al., 2008). Excess Water is not available in extrusion and the starch granules do not swell and rupture, as in Classical gelatinization, but are instead mechanically disrupted by high shear forces and drastic pressure changes resulting in disappearance of native starch crystallinity, plasticization, expansion of the food structure, reduced paste viscosity, loss of water holding, increased reconstitutability of the extrudate, softer product texture and changes in colour (Onyango et al., 2004). 
152 Afr. J. Food Sci. Technol.

Functionality of a food is a property of a food ingredient apart from its nutritional value which has a great impact on its utilisation. For extrudate snack product water absorption index WAI is one of the critical quality characteristics taken in to consideration. This is owing to its important implications on hydration properties of such product. Water absorption index WAI depends on the availability of hydrophilic groups which bounds water molecules and on the gel forming capacity of macromolecules. WAI is the measure of swelling power of the starch (Anderson et al., 1996). On the other hand water solubility index WSI expresses the percentage of dry matter recovered after the supernatant is evaporated from water absorption determination (Anderson et al., 1996). Water solubility index WSI is related to the q1uantity of soluble molecules which is related to starch dextrinisation. Water hydration capacity has been used as measure of quality attributes of extrudate product and considered as indicator of starch gelatinisation (Ding et al., 2005, 2006). The water holding capacity of any blend depends on the availability of hydrophilic groups that binds water molecules and on the gel forming capacity of macromolecules (Onyeka and Dibia, 2002). A high water holding capacity WHC reflects high starch content. Viscosity depends on solubility and water holding capacity as well as the structure of components in food. Viscosity profile can be thought of as a reflection of the granular changes in the starch granule that occur during gelatinization, (Thomas and Atwell, 1997). Today, extruders are used in a variety of applications in food processing industries. Extrusion offers a way to cook, shape, and pasteurize different products. It permits better utilization of available cereal grains, as well as vegetable and animal proteins, in manufacturing cost-effective and nutritionally balanced diets with unique and improved characteristics (Jager et al., 1992). The objective of this work was to study the effect of feed composition, feed moisture and barrel temperature on the water absorption index, water solubility index, water hydration capacity and viscosity of extruded dakuwa from blends of sorghum, groundnut and tigernut using three factor three level full factorial experimental design.

\section{MATERIALS AND METHODS}

\section{Sources of raw material}

Sorghum ( Sorghum bicolour $L$ ) red variety, Groundnut (Arachis hypogeal L) red skin, Tiger nut (Cyperus esculentus $L$ ) brown variety and Granulated red pepper (Capsicum annum) were all procured in Jimeta modern market, Yola north local government area of Adamawa State.

\section{Preparation of raw materials}

The raw materials which comprised of Sorghum,
Groundnut and Tiger nut were sorted manually, cleaned and washed with clean water and it was dried in conventional oven at $50^{\circ} \mathrm{C}$ for 1 hour, the raw materials were roasted at $150{ }^{\circ} \mathrm{C}$ for 30 minutes in baking oven. They were grinded to flour, standard sieve were used in sieving and the particle size of $0.05 \mathrm{~mm}$ was obtained. And groundnut was grinded to paste using grinding machine ( $7 \mathrm{hp}$ India). The sorghum, groundnut and tiger nut grits was mixed together in a ratio of 50:20:30 50:25:25 50:30:20 respectively. To $1.5 \mathrm{~kg}$ of this mixture $2.5 \%$ of granulated red pepper (Capsicum annum) was added. The mixture was then extruded using extruding machine. The extruded were allowed to cool and functional properties were then analysed.

\section{Full factorial design}

To construct an approximation model that can capture interactions between $N$ design variables, a full factorial approach may be necessary to investigate all possible combinations (Montgomery, 1997). A factorial experiment is an experimental strategy in which design variables are varied together, instead of one at a time. The lower and upper bounds of each of $N$ design variables in the optimization problem needs to be defined. The allowable range is then discretized at different levels. If each of the variables is defined at only the lower and upper bounds (two levels), the experimental design is called $2^{N}$ full factorial. Similarly, if the midpoints are included, the design is called $3^{N}$ full factorial. Factorial designs can be used for fitting second-order models. A second-order model can significantly improve the optimization process when a first-order model suffers lack of fit due to interaction between variables and surface curvature. A general second-order model is defined as

$$
y=a_{o}+\sum_{i=1}^{n} a_{i} x_{i}+\sum_{i=1}^{n} a_{i i} x^{2}{ }_{i}+\sum_{i=1}^{n} \sum_{i=1}^{n} a_{i j} x_{i} x_{j}
$$

Where $x i$ and $x j$ are the design variables and $a$ are the tuning parameters. The construction of a quadratic response surface model in $N$ variables requires the study at three levels so that the tuning parameters can be estimated. Therefore, at least $(N+1)(N+2) / 2$ function evaluations are necessary. Generally, for a large number of variables, the number of experiments grows exponentially $\left(3^{N}\right.$ for a full factorial) and becomes impractical. A full factorial design typically is used for five or fewer variables. However in this experiment three factor three levels full factorial design were used for the design as shown in table 1 and 2 (Yusuf et al., 2017).

\section{Experimental Design}

A Three factor Three level Experimental Design $(3 \times 3 \times 3)$ was use to determine the effect of extrusion on the 
Table 1.Factors and levels of the $3 \times 3 \times 3$ full factorial experimental design

\begin{tabular}{|c|c|c|c|c|}
\hline & Symbol & Factor & & \\
\hline Factors & & 1 & 2 & 3 \\
\hline $\begin{array}{l}\text { Barrel temperature }\left({ }^{0} \mathrm{C}\right) \\
\text { Feed compositon }\end{array}$ & $\overline{X_{1}}$ & 90 & 100 & 110 \\
\hline $\begin{array}{l}\text { (Sorghum, groundnut, tigernut) } \\
\text { Feed moisture (\%) }\end{array}$ & $\begin{array}{l}X_{2} \\
X_{3}\end{array}$ & $\begin{array}{c}50: 20: 30 \\
18\end{array}$ & $\begin{array}{c}50: 25: 25 \\
22\end{array}$ & $\begin{array}{c}50: 30: 20 \\
26\end{array}$ \\
\hline
\end{tabular}

Table 2. Experimental Design of Extrusion Experiment in their Coded Form

\begin{tabular}{|c|c|c|c|}
\hline \multirow[b]{2}{*}{ Runs } & \multicolumn{2}{|c|}{ Independent variables in coded form } & \\
\hline & $\begin{array}{l}\text { Bt }\left(X_{1}\right) \\
\text { Levels } \\
123\end{array}$ & $\begin{array}{l}\text { Fc }\left(X_{2}\right) \\
\text { Levels } \\
123\end{array}$ & $\begin{array}{r}\mathrm{Fm}\left(\mathrm{X}_{3}\right) \\
\text { Levels } \\
123\end{array}$ \\
\hline 1 & 1 & 3 & 2 \\
\hline 2 & 1 & 3 & 1 \\
\hline 3 & 1 & 3 & 3 \\
\hline 4 & 1 & 2 & 2 \\
\hline 5 & 1 & 2 & 1 \\
\hline 6 & 1 & 2 & 3 \\
\hline 7 & 1 & 1 & 2 \\
\hline 8 & 1 & 1 & 1 \\
\hline 9 & 1 & 1 & 3 \\
\hline 10 & 2 & 2 & 3 \\
\hline 11 & 2 & 2 & 2 \\
\hline 12 & 2 & 2 & 1 \\
\hline 13 & 2 & 3 & 1 \\
\hline 14 & 2 & 3 & 2 \\
\hline 15 & 2 & 3 & 3 \\
\hline 16 & 2 & 1 & 1 \\
\hline 17 & 2 & 1 & 3 \\
\hline 18 & 2 & 1 & 2 \\
\hline 19 & 3 & 2 & 3 \\
\hline 20 & 3 & 2 & 3 \\
\hline 21 & 3 & 2 & 1 \\
\hline 22 & 3 & 1 & 1 \\
\hline 23 & 3 & 1 & 3 \\
\hline 24 & 3 & 1 & 2 \\
\hline 25 & 3 & 3 & 3 \\
\hline 26 & 3 & 3 & 2 \\
\hline 27 & 3 & 3 & 1 \\
\hline
\end{tabular}

functional properties of Nigerian indigenous cereals and legume based snack product (Dakuwa).The extrusion variables that were considered includes: Feed moisture content (Fm), Barrel temperature (Bt) and Feed composition ( $\mathrm{Fc})$, each were varied at 3,3 and 3 levels respectively as shown in Table 1 and 2 . Thus, this is a 3 (feed moisture) $\times 3$ (barrel temperature) $\times 3$ (feed composition) full factorial design treatment for a mixture of flour. The analysis of variance was carried out to investigate the effect of operating conditions on the final extruded product quality using version 16 of Gen stat software (Genstat, 2013).

\section{Extrusion processing}

The extrusion cooking process was performed using a pilot scale co-rotating twin screw food extrusion cooker (SLG65-III Model China) the extruder has a feeder at the top with constant feed rate, it also has a control panel board where the barrel temperature was set. The 
154 Afr. J. Food Sci. Technol.

Table 3. Combine Effect of Extrusion Variables on Functional Properties of Dakuwa Extruded

\begin{tabular}{|c|c|c|c|c|c|c|c|}
\hline $\begin{array}{l}\text { SN } \\
\text { Level }\end{array}$ & $\frac{B t}{123}$ & $\frac{F c}{123}$ & $\frac{\mathrm{Fm}}{123}$ & WAI & $\begin{array}{l}\text { WSI } \\
(\%)\end{array}$ & $\begin{array}{l}\text { WHC } \\
(\%)\end{array}$ & Viscosity (mpas) \\
\hline 1 & 1 & 3 & 2 & $2.35^{a}$ & $6.67^{\mathrm{b}}$ & $1.35^{\mathrm{c}}$ & $7.68^{c}$ \\
\hline 2 & 1 & 3 & 1 & $2.11^{a}$ & $12.13^{\mathrm{b}}$ & $1.15^{\mathrm{c}}$ & $7.84^{\mathrm{bc}}$ \\
\hline 3 & 1 & 3 & 3 & $1.82^{\mathrm{ab}}$ & $5.73^{1}$ & $0.82^{\mathrm{cd}}$ & $6.48^{\mathrm{d}}$ \\
\hline 4 & 1 & 2 & 2 & $2.03^{\mathrm{a}}$ & $8.13^{\dagger}$ & $1.03^{c}$ & $8.78^{b}$ \\
\hline 5 & 1 & 2 & 1 & $2.49^{a}$ & $10.40^{d}$ & $1.49^{c}$ & $8.15^{\mathrm{b}}$ \\
\hline 6 & 1 & 2 & 3 & $2.13^{\mathrm{a}}$ & $8.13^{\dagger}$ & $1.13^{c}$ & $8.91^{\mathrm{ab}}$ \\
\hline 7 & 1 & 1 & 2 & $2.27^{\mathrm{a}}$ & $8.80^{\text {et }}$ & $1.27^{c}$ & $8.61^{\mathrm{b}}$ \\
\hline 8 & 1 & 1 & 1 & $1.89^{\mathrm{ab}}$ & $10.53^{d}$ & $0.90^{\text {cd }}$ & $9.24^{\mathrm{a}}$ \\
\hline 9 & 1 & 1 & 3 & $2.26^{\mathrm{a}}$ & $8.80^{\text {et }}$ & $1.25^{\mathrm{c}}$ & $8.63^{b}$ \\
\hline 10 & 2 & 2 & 3 & $2.34^{\mathrm{a}}$ & $9.60^{\mathrm{e}}$ & $1.16^{\mathrm{c}}$ & $8.57^{\mathrm{b}}$ \\
\hline 11 & 2 & 2 & 2 & $2.16^{\mathrm{a}}$ & $9.33^{\mathrm{e}}$ & $1.16^{c}$ & $7.72^{c}$ \\
\hline 12 & 2 & 2 & 1 & $2.06^{a}$ & $7.87^{\mathrm{g}}$ & $1.06^{c}$ & $8.60^{b}$ \\
\hline 13 & 2 & 3 & 1 & $2.09^{a}$ & $6.00^{n}$ & $1.10^{c}$ & $8.98^{a b}$ \\
\hline 14 & 2 & 3 & 2 & $2.17^{\mathrm{a}}$ & $7.73^{\mathrm{g}}$ & $2.93^{d}$ & $8.94^{\mathrm{ab}}$ \\
\hline 15 & 2 & 3 & 3 & $2.23^{a}$ & $10.80^{\mathrm{cd}}$ & $4.95^{\mathrm{a}}$ & $8.92^{\mathrm{ab}}$ \\
\hline 16 & 2 & 1 & 1 & $2.16^{\mathrm{a}}$ & $8.13^{\dagger}$ & $3.44^{\mathrm{e}}$ & $8.27^{b}$ \\
\hline 17 & 2 & 1 & 3 & $2.32^{\mathrm{a}}$ & $8.40^{\dagger}$ & $1.32^{c}$ & $8.33^{b}$ \\
\hline 18 & 2 & 1 & 2 & $1.98^{\mathrm{ab}}$ & $13.87^{a}$ & $0.97^{\mathrm{cd}}$ & $9.03^{a}$ \\
\hline 19 & 3 & 2 & 3 & $2.19^{a}$ & $10.53^{d}$ & $3.59^{b}$ & $8.54^{b}$ \\
\hline 20 & 3 & 2 & 3 & $2.14^{a}$ & $11.60^{\circ}$ & $1.14^{c}$ & $9.20^{\mathrm{a}}$ \\
\hline 21 & 3 & 2 & 1 & $2.23^{a}$ & $8.93^{\text {et }}$ & $1.33^{c}$ & $8.27^{b}$ \\
\hline 22 & 3 & 1 & 1 & $2.02^{a}$ & $5.73^{\prime}$ & $0.96^{c d}$ & $8.44^{b}$ \\
\hline 23 & 3 & 1 & 3 & $2.21^{a}$ & $11.73^{c}$ & $1.21^{\mathrm{c}}$ & $6.96^{\mathrm{cd}}$ \\
\hline 24 & 3 & 1 & 2 & $2.17^{\mathrm{a}}$ & $8.53^{\dagger}$ & $1.17^{\mathrm{c}}$ & $6.74^{d}$ \\
\hline 25 & 3 & 3 & $\begin{array}{l}2 \\
3\end{array}$ & $2.11^{\mathrm{a}}$ & $10.00^{d}$ & $1.11^{\mathrm{c}}$ & $9.23^{\mathrm{a}}$ \\
\hline 26 & 3 & $\begin{array}{l}3 \\
3\end{array}$ & 2 & $2.10^{\mathrm{a}}$ & $10.80^{\mathrm{cd}}$ & $1.10^{\mathrm{c}}$ & $8.41^{\mathrm{b}}$ \\
\hline $\begin{array}{l}20 \\
27\end{array}$ & $\begin{array}{l}5 \\
3\end{array}$ & 3 & $\begin{array}{l}2 \\
1\end{array}$ & $2.42^{a}$ & $7.87^{\mathrm{g}}$ & $1.42^{\mathrm{c}}$ & $7.45^{\circ}$ \\
\hline Extruded & & & & $2.17^{a}$ & $9.14^{\mathrm{e}}$ & $1.54^{c}$ & $8.33^{b}$ \\
\hline Un extruded & & & & $2.05^{\mathrm{a}}$ & $4.49^{i}$ & $1.05^{c}$ & $11.06^{\mathrm{e}}$ \\
\hline $\begin{array}{l}\text { Percentage } \\
\text { increase/decrease } \\
\text { (\%). }\end{array}$ & & & & 5.50 & 50.9 & 31.8 & 32.7 \\
\hline
\end{tabular}

$\mathrm{Bt}=$ barrel temperature, 1 represent $90{ }^{\circ} \mathrm{C}$ barrel temperature, 2 represent $100{ }^{\circ} \mathrm{C}$ barrel temperature, 3 represent $110{ }^{\circ} \mathrm{C}$ barrel temperature. $\mathrm{FC}=$ feed composition, 1 represent $50 \% 25 \% 25 \%$, 2 represent $50 \% 30 \% 20 \%$, 3 represent $50 \% 20 \%$ $30 \%$. $\mathrm{Fm}=$ feed moisture, 1 represent $18 \%, 2$ represent $22 \%, 3$, represent $26 \%$. Mean with the same superscript within a column are not significantly different $(p>0.05)$ values are triplicate of means.

machine has constant screw speed of $150 \mathrm{rpm}$ and a die diameter of $3 \mathrm{~mm}$. The twin screws within the barrel are surrounded with heaters controlled at the control panel board Figure 3 shows the picture of the extruder. The grits was alternatively feed in to the extruder inlet by volumetric feeder. The temperature of the three zones of the extruder was controlled by Eurotherm controller and was read on separate control panel board. Extruded samples were collected when the extrusion process parameters reach steady states. Steady state was reached when there was no visible drift in torque and die pressure.

Necessary calibration and adjustment of the barrel temperature of the extruder was performed prior to the main extrusion cooking process. Feed rate and screw speed were constant. The feed composition was varied at $50: 20: 30,50: 25: 25$ and 50:30:20 ratios of sorghum, groundnut and tiger nut respectively. The barrel temperature of zone three, which was located just before the die was allowed to operate at different temperatures ranging from $90{ }^{\circ} \mathrm{C}$ to $110{ }^{\circ} \mathrm{C}$. By looking at the characteristic of the products from the extrusion, the barrel temperature was selected for the experiment. The moisture content of the material was adjusted to give moisture contents of $18 \%, 22 \%$ and $26 \%$ by using hydration equation (1).

$W_{a}=\mathrm{S}_{\mathrm{W}} \times\left(\frac{M-M o}{100-M}\right)$

Where:

Wa $=$ Weight of water added $(\mathrm{g})$

$\mathrm{S}_{\mathrm{w}}=$ Sample flour weight $(\mathrm{g})$

$M_{0}=$ Original flour moisture content (\% weight base)

$M=$ Required dough moisture level (\% weight base).

The extrusion experiment was conducted using the experimental design shown in Table 2. 



Bt: Barrel temperature
Fc: Feeds composition
Fm: Feeds moisture

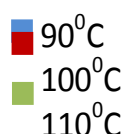

$50: 20: 30$

$50: 25: 25$

$50: 30: 20$
$18 \%$
$22 \%$
$26 \%$

Figure 1. Effect of extrusion Independent variables on the WAI of the extrudate

\section{Water absorbing index}

Water absorption index (WAl) of extrudate was determined according to Anderson et al. (1969). $2.5 \mathrm{~g}$ of the finely ground sample was suspended in $30 \mathrm{ml}$ of distilled water in a tarred $50 \mathrm{ml}$ centrifuge tube and were shake for $30 \mathrm{~min}$. The sample was centrifuge for $10 \mathrm{~min}$ at $3000 \mathrm{rpm}$. The clear supernatant of the centrifugation was transferred into pre-dried and weighed glass baker for the estimation of the water solubility index (WSI). The gel remaining in the centrifuge tube was weighed and WAI was calculated as follows:

$\mathrm{WAl}=\frac{\mathrm{w}_{\mathrm{g}}}{\mathrm{w}_{\mathrm{ds}}} \times 100$

Where:

WAI = water absorption Index

$\mathrm{W}_{\mathrm{g}}=$ weight of the gel

$\mathrm{W}_{\mathrm{ds}}=$ weight of dry sample

\section{Water solubility index (WSI)}

The supernatant preserved from (WAl) measurement was evaporated at $96^{\circ} \mathrm{C}$ temperature for overnight on water bath. The WSI was calculated as

$\mathrm{WSI}=\frac{\mathrm{W}_{\mathrm{sg}}}{\mathrm{W}_{\mathrm{ds}}} \times 100$

Where:

WSI = water solubility index

$\mathrm{W}_{\mathrm{ss}}=$ weight of dry solid supernatant

$\mathrm{W}_{\mathrm{ds}}=$ weight of dry sample

\section{Water hydration capacity}

The Water hydration capacity (WHC) of the formulated flour and extrudate was estimated according to AOAC 
(2000) official method of 56-20. $2 \mathrm{~g}$ of sample was measured in about $100 \mathrm{ml}$ centrifuge tube, $40 \mathrm{ml}$ water was added; shake vigorously to thoroughly suspend the sample. After the sample suspension stands for 10 minutes, it was centrifuged for 15 minutes at 3000rpm. The clear supernatant was drained on pre -weighed and dried beaker for estimation of the WSI of the product. The hydration capacity was calculated as follows

$$
\text { WHC }-\frac{\text { (weight of sediment-weight of sample) }}{\text { weight of sample }} \times 100 \text {----------Eq. (5) }
$$

$\mathrm{WHC}=$ water hydration capacity

\section{Viscosity}

The viscosity of the sample was determined using VIBRO VISCOMETER (SV-10 model) with accuracy of 0.3$10000 \mathrm{mpas}$. The viscometer uses the principle of turning fork. The vibro viscometer has two vibrating plate with a sensor that measure the temperature. The frequency of vibration of the plate determine the viscosity of the sample. $5 \mathrm{~g}$ of the sample was suspended in $50 \mathrm{ml}$ of water. The viscosity was measured at room temperature. The machine was allowed to run for 20 minutes and the value of the viscosity was recorded from the digital meter of vibro viscometer.

\section{Statistical Analyses}

The Analysis of variance (ANOVA) was conducted using Genstat software (Genstat, 2013). Significance was accepted at 0.05 level of probability $(p<0.05)$. Mean separation was performed by Least Significant Difference (LSD) for multiple comparisons of means. All the graphical presentations were carried out using Microsoft of excel and 3D histogram was used to present the effect of independent extrusion variables on functional properties of the extrudates as shown in figures provided.

\section{RESULT AND DISCUSSION}

\section{Effect of Extrusion Operating Variables on Functional Properties of the Extrudates}

\section{Water absorption index (WAl)}

The effect of independent variables on functional properties of the extruded is shown in table 3 . The lowest water absorption index of $1.82 \mathrm{~g} / \mathrm{g}$ was recorded at design point 3 representing $90{ }^{\circ} \mathrm{C}$ barrel temperature 50:30:20 feed composition for sorghum groundnut and tigernut and $26 \%$ feed moisture content. On the other hand the highest water absorption index value of 2.49 was recorded at design point 5 representing $90{ }^{\circ} \mathrm{C}$ barrel temperature 50:20:30 feed composition for sorghum groundnut and tigernut and $18 \%$ feed moisture content.

The lowest water absorption index recorded at design point 3 could be as a result of feed composition, the formulation with high percentage of groundnut $30 \%$ recorded least water absorption index, the high fat content of groundnut decreases the water absorption index. Mean while formulation with $25 \%$ groundnut content and tigernut recorded high water absorption index that should be because of tigernut content that contains carbohydrate that aids water absorption as shown in Table 3. On linear model significant difference $(p>0.05)$ was not observed on barrel temperature, however feed composition and feed moisture significantly $(p<0.05)$ affected the water absorption index of the extrudates. The quadratic and interaction models also significantly $(p<0.05)$ affected the water absorption index of the extrudates. As barrel temperature (BT) increased from 90 to $100{ }^{\circ} \mathrm{C}$ WAl increased from $2.15 \mathrm{~g} \mathrm{gel} / \mathrm{g}$ solid to 2.18 respectively, but further increase of barrel to 110 ${ }^{0} \mathrm{C}$ resulted in decrease in WAI to $2.16 \mathrm{~g}$ gel $/ \mathrm{g}$ solid figure 1.

But in some cases higher increasing of the temperature will caused the decrease in WAl. Colonna and Mercier (1983) reported that increasing extrusion temperature from 150 to $180^{\circ} \mathrm{C}$ decreased the WAl that should be as a result of starch degradation. The changes in the WAI would be due the variables used in the study. An increase in the plasticisation of starch granules opened their structure which result in higher water absorption and promote the increase in water absorption. As the feed composition increased from 50:20:30 to $50: 25: 25$ WAl increased from 2.17 to 2.21. But at 50:30:20 WAl decreased to 2.13, and the reason could be because of $30 \%$ groundnut content in the blend which has oil content that decreased the water solubility index of the extrudate. As Feed moisture content increased from 18 to $22 \%$ WAl increased from 2.12 to $2.25 \%$, however at $26 \%$ moisture WAI decreased to $2.13 \%$ figure 1.

The water absorption index of flour mixture and its extrudate was found to be $2.05 \mathrm{~g} \mathrm{gel} / \mathrm{g}$ solid and $2.17 \mathrm{~g}$ $\mathrm{gel} / \mathrm{g}$ solid respectively with extruded recording the highest value of $2.17 \mathrm{~g} \mathrm{gel} / \mathrm{g}$ solid. The result clearly indicates that water absorption index (WAI) value of the extrudate is greater than that of the formulated flour with a percentage increase of $5.5 \%$.

This shows that there was a starch gelatinisation, protein denaturation and swelling of crude fibre which occurs during extrusion could all be responsible for the increasing of WAI value of extrudate product (Gujska and Khan, 1991). WAl of extrudate product is higher than that of the flour before extrusion because during extrusion starch gelatinisation would take place and WAI is an index of gelatinisation since native starch does not 


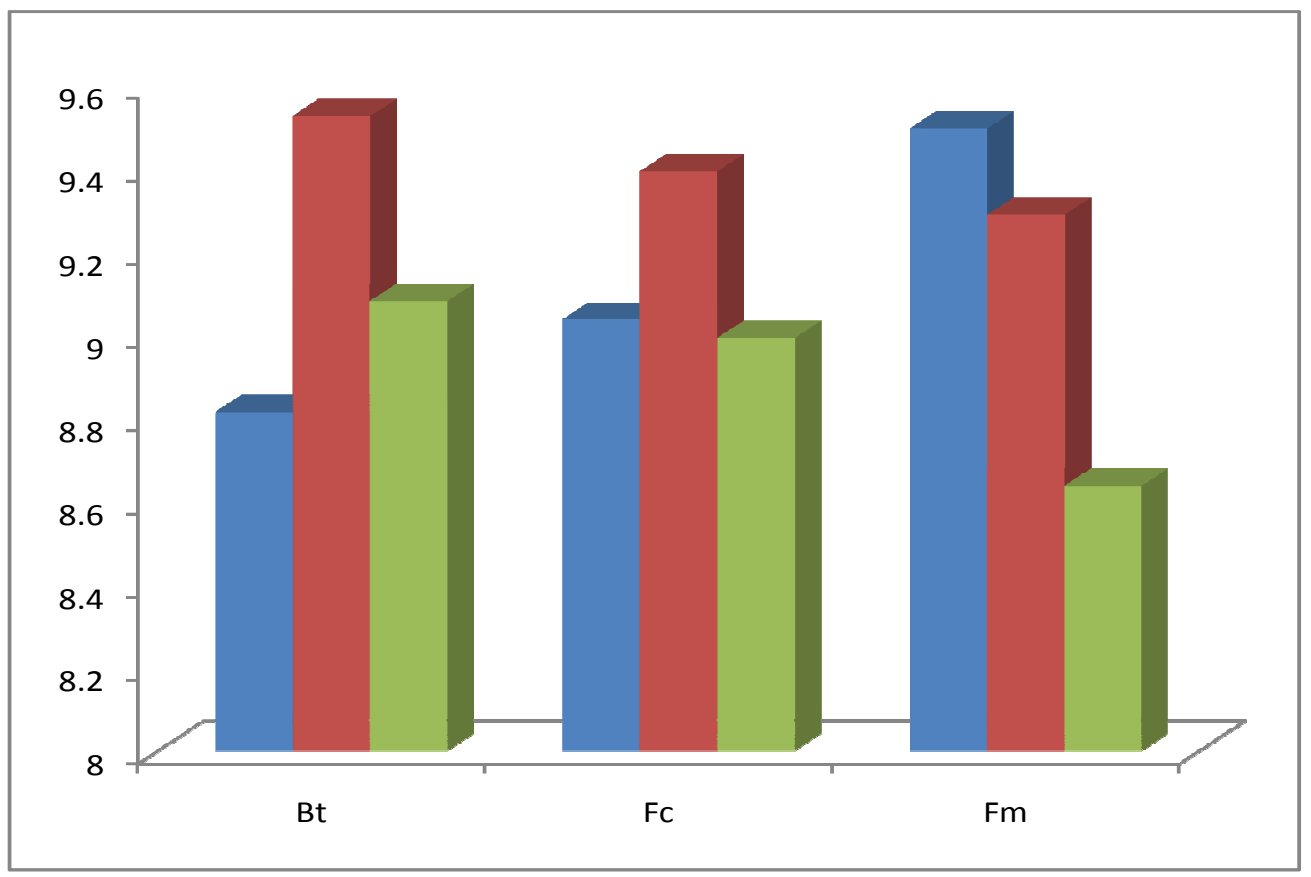

Bt: Barrel temperature

Fc: Feeds composition

(Sorghum:Graundnut:Tigernut)

$$
\begin{aligned}
& 90^{\circ} \mathrm{C} \\
& -100^{\circ} \mathrm{C} \\
& 110^{\circ} \mathrm{C}
\end{aligned}
$$

$50: 20: 30$
$50: 25: 25$

$50: 30: 20$
Fm: Feeds moisture

$18 \%$

$22 \%$

$26 \%$

Figure 2. Effect of Extrusion Independent variables on WSI of the extrudate

absorb water at room temperature (Ding et al., 2006).

\section{Water Solubility Index (WSI)}

The least water solubility index (WSI) value of $5.73 \%$ was recorded at design point 12 repr1esenting $100{ }^{\circ} \mathrm{C}$ barrel temperature, 50:25:25 feed composition for sorghum groundnut and tigernut and $18 \%$ feed moisture content. And the highest value of $12.13 \%$ was recorded at design point 26 representing $110^{\circ} \mathrm{C}$ barrel temperature 50:30:20 feed composition for sorgh1um groundnut and tigernut and $22 \%$ feed moisture content. The lowest water solubility index recorded at design point 12 could be as a result of barrel temperature, since starch gelatinisations occur at high temperature and that increases the water solubility index. On linear model Significant difference ( $p>0.05$ ) was not observed on barrel temperature, feed composition and feed moisture content, however on quadratic and interaction models significant difference $(p<0.05)$ was observed on barrel temperature, feed composition and feed moisture content on the water solubility index of the extrudate. As the barrel temperature increased from $90{ }^{0} \mathrm{C}$ to $100{ }^{\circ} \mathrm{C}$ the water solubility index WSI increased from $8.81 \%$ to $9.52 \%$ but at $110{ }^{\circ} \mathrm{C}$ the water solubility index WSI decreased to $9.08 \%$. As the feed composition increased from 50:20:30 to $50: 25: 25$ the water solubility index WSI increased from $9.03 \%$ to $9.39 \%$ however at 50:30:20 the water solubility index WSI decreased to $8.99 \%$. feed moisture content negatively affect the water solubility index of the extrudate, as the feed moisture content increased from $18 \%$ to $22 \%$ water solubility index decreased from 9.49 $\%$ to $9.28 \%$ and $8.63 \%$ at $26 \%$ as shown in figure 2 . Extrusion significantly $(p<0.05)$ affect the water solubility index (WSI) of the extrudate. The water solubility index of formulated flour and the extrudate were $4.49 \%$ and 9.14 $\%$ respectively. $50.9 \%$ increase in water solubility index was recorded as a result of extrusion.

This showed that WSI value of extrudates are significantly higher $(p<0.05)$ than that of formulated flour mixture. These clearly indicate that there was higher starch dextrinisation or gelatinisation which could increase the amount of soluble matters during the 
158 Afr. J. Food Sci. Technol.



Bt: Barrel temperature Fc: Feeds composition $\quad$ Fm: Feeds moisture

(Sorghum:Graundnut:Tigernut)

$\begin{array}{lrr}90^{\circ} \mathrm{C} & 50: 20: 30 & 18 \% \\ \square 100^{\circ} \mathrm{C} & 50: 25: 25 & 22 \% \\ 110^{\circ} \mathrm{C} & 50: 30: 20 & 26 \%\end{array}$

Figure 3. Effect of Extrusion Independent variables on WHC of the extrudate

extrusion cooking process. Ryes et al. (2002) reported that WSI is related to the presence of soluble molecules which has been related to dextrinisation. An increase in WSI shows macromolecular degradation with intensity of extrusion condition (Leak, 2006).

\section{Water Hydration Capacity (WHC)}

The least water holding capacity (WHC) of $0.82 \%$ of extrudate were recorded at design point 3 representing $90{ }^{\circ} \mathrm{C}$ barrel temperature 50:30:20 feed composition for sorghum groundnut and tiger nut and $26 \%$ feed moisture content. The highest value of $4.95 \%$ were recorded at design point 15 representing $100{ }^{\circ} \mathrm{C}$ barrel temperatures, 50:30:20 feed composition for sorghum groundnut and tigernut and $26 \%$ feed moisture content. The low value of water holding capacity is observed at $90{ }^{\circ} \mathrm{C}$ barrel temperature while the highest value was at $100{ }^{\circ} \mathrm{C}$ barrel temperature therefore the highest value observed at the highest temperature could be as a result of starch gelatinisation that increases the water holding capacity of the extrudate. Significant difference $(p>0.05)$ was not observed for barrel temperature, feed composition and feed moisture content on the linear model but quadratic and interaction were significant $(p<0.05)$ on the water holding capacity of the extrudate. Increasing barrel temperature from $90{ }^{\circ} \mathrm{C}$ to $110{ }^{\circ} \mathrm{C}$ resulted in increase in water hydration capacity from $1.15 \%$ to $2.01 \%$. On the other hand increasing feed composition from 50:20:30 to 50:30:20 resulted in decrease in water holding capacity from $1.78 \%$ to $1.37 \%$. feed moisture content showed positive effect on the water holding capacity of the extrudate, as the feed moisture in 11 creased from $18 \%$ to $26 \%$ the water holding capacity increased from $1.11 \%$ to $1.84 \%$ as shown in figure 3 .

The water hydration capacity (WHC) value of formulated flour mixture and extrudate were $1.05 \%$ and $1.54 \%$ respectively. WHC of extrudate is significantly higher $(p<0.05)$ than that of the formulated flour mixture 


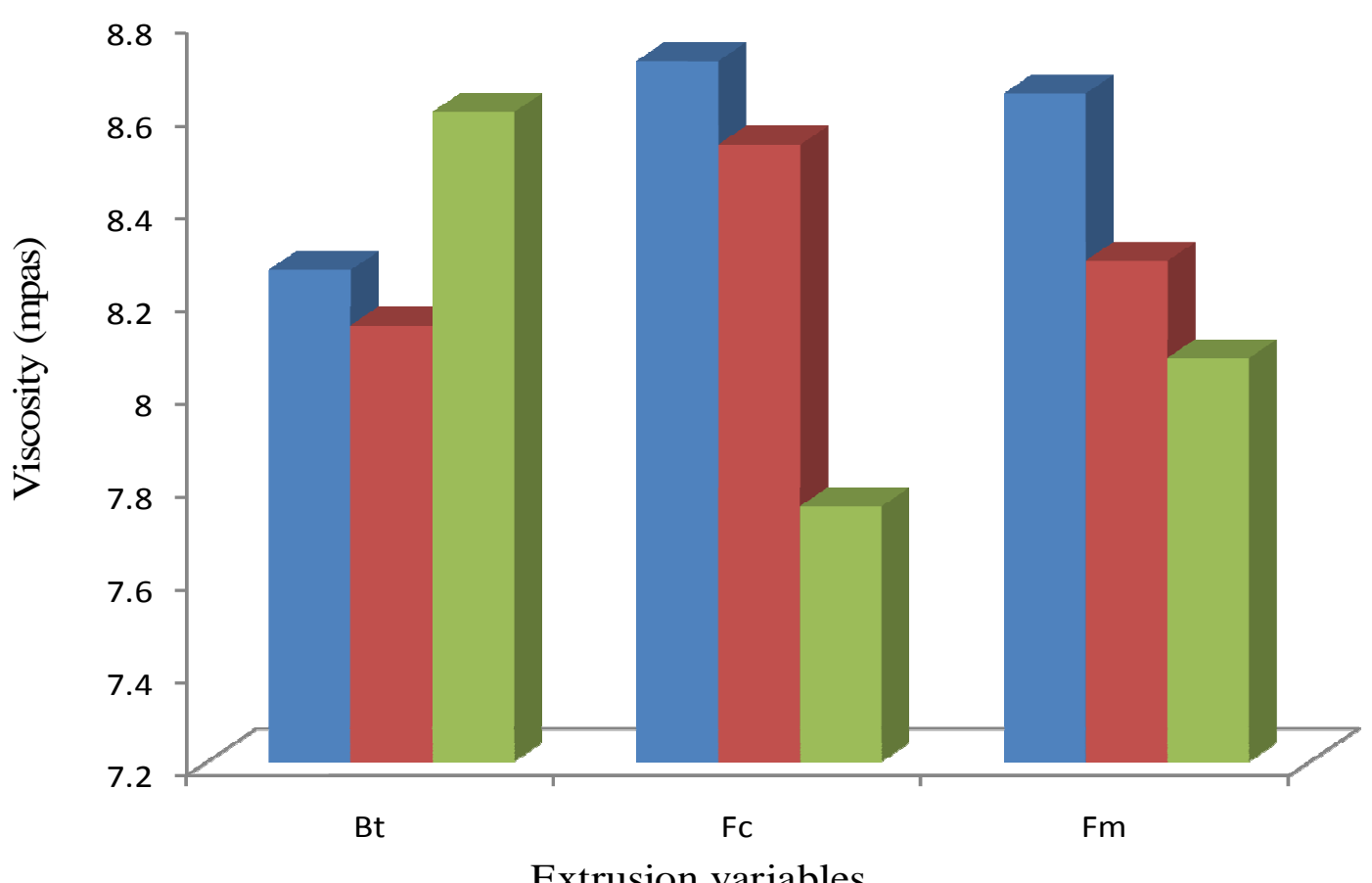

Bt: Barrel temnerature

$90^{\circ} \mathrm{C}$
$100^{\circ} \mathrm{C}$
$110^{\circ} \mathrm{C}$
Fc: Feeds comnosition

$50: 20: 30$

$50: 25: 25$

$50: 30: 20$
Fm: Feeds moisture

$18 \%$

$22 \%$

$26 \%$

Figure 4. Effect of Extrusion Independent variables on the viscosity of the extrudate

with percentage increase of $31.8 \%$ of non extrudate (raw) to extrudate. This indicates that there was starch gelatinisation ring of the extrusion cooking process. The water holding capacity of protein is very important because it affect the texture and also the ability of soy protein to bind and retain water and enhances the shelf life of bakery products (Hettiarachchy and kalapathy, 1997). The water holding capacity of any blend depends on the availability of hydrophilic groups that binds water molecules and on the gel forming capacity of macromolecules (Onyeka and Dibia, 2002).

\section{Viscosity}

The least viscosity value of 6.48 mpas was recorded at design point 3 representing $90{ }^{\circ} \mathrm{C}$ barrel temperature 50:30:20 feed composition for sorghum groundnut and 1111 tigernut and $26 \%$ feed moisture content. However the highest value of 9.23 mpas were recorded at design point 8 representing $90{ }^{\circ} \mathrm{C}$ barrel temperature 50:20:30 feed composition for sorghum groundnut and tigernut and $18 \%$ feed moisture content. The least viscosity recorded at design point 3 could be as a result of incorporation of $30 \%$ groundnut content in the blend, therefore the high fat content decrease the viscosity. On the other hand the high viscosity recorded at design point 8 is due to the incorporation of $30 \%$ tigernut content that is rich in carbohydrates that increase the viscosity. On linear model significant difference $(p>0.05)$ was not observed on barrel temperature and feed moisture content however it was observed on feed composition. On quadratic and interaction significant difference $(p<0.05)$ were observed on barrel temperature, feed composition and feed moisture content on the viscosity of the extrudates. Viscosity decrease with increase in feed moisture content from 8.64 at $18 \%$ to 8.07 at $26 \%$. Viscosity decrease with increase in barrel temperature from 8.25 at $90{ }^{\circ} \mathrm{C}$ to 8.13 at $100{ }^{\circ} \mathrm{C}$. However it further increased to 8.59 at $110^{\circ} \mathrm{C}$. Feed composition significantly $(\mathrm{p}<0.05)$ affect the viscosity of the extrudate with 8.71 mpas at 50:20:30 to 8.52 mpas at 50:25:25, however the lowest viscosity value of 7.75 mpas was recorded at 50:30:20 and this could be attributed to high percentage of groundnut that contains oil, that reduces the viscosity of extrudate as shown in Figure 4. 
160 Afr. J. Food Sci. Technol.

Table 4. Optimum values of independent variables for WAI, WSI WHC and VISCOSITY

\begin{tabular}{lcccc}
\hline Response variables & \multicolumn{4}{c}{ Independent variables } \\
WAI & Barrel temp & Feed composition & Feed moisture & Optimum value \\
WSI & $90^{\circ} \mathrm{C}$ & $50: 20: 30$ & $18 \%$ & 2.49 \\
WHC & $110^{\circ} \mathrm{C}$ & $50: 30: 20$ & $22 \%$ & 12.13 \\
VISCOSITY & $100^{\circ} \mathrm{C}$ & $50: 30: 20$ & $26 \%$ & 4.95 \\
\hline
\end{tabular}

Extrusion significantly $(p<0.05)$ affected the viscosity of the extrudate, with extrudate having the lowest value of $8.33 \mathrm{mpas}$ and the un extrudate $11.06 \mathrm{mpas}$ with percentage decrease of $32.7 \%$ of extrudate to non extrudate. The reduction of viscosity of the extrudate could be as a result of starch dextrinisation which resulted in decrease of viscosity in all gruels and a concomitant increase in caloric and nutrient density of extrudate. Hagenimana et al. (2006) reported viscosity values of extrudate rice flours were far less than those of their corresponding unprocessed rice flour dispersed in micro viscoamylograph (MVAG) indicating that their starches have been partially pregelatinised by extrusion process they reported that peak viscosity indicated a high positive correlation with hot paste viscosity and cold paste viscosity. Report by Bhattacharya and Hana, (1986) revealed that viscosity of protein would depend on solubility and water holding capacity as well as the structural nature of the extrudates. The report indicated that, globular structures can be expected to be more viscous than the linear structures.

\section{Optimum conditions}

The combination of 900C barrel temperature, 50:20:30 feed composition for sorghum 1groundnut and tiger nut, $18 \%$ moisture content resulted in optimal value of WAI of 2.49. On the other hand the combination $1100 \mathrm{C}$ barrel temperature, 50:30:20 feed composition for s1orghum, groundnut and tigernut, $18 \%$ feed moisture content resulted in optimum value of 121.13 for WSI. The combine effect 1000C barrel temperature, 50:30:20 feed composition for sorg1hum groundnut and tigernut, $26 \%$ feed moisture yielded an optimum value of 4.95 for WHC11. The combination of $900 \mathrm{C}$ barrel temperature 50:20:30 feed composition for sorghum groundnut and tigernut and $18 \%$ feed moisture content resulted in an optimum value of viscosity of $9.23 \mathrm{mps}$.

\section{CONCLUSION}

Dakuwa extrudates was produced from blends of sorghum groundnut and tigernut. The aims of adapting extrusion process in the development of dakuwa extrudate was to improve its quality functionality enhancing its shelf life, physical state and its e1nd use characteristics. Three factor three level full factorial experimental design was used in determining the functional properties of dakuwa extrudate which include water absorption index, water solubility index water hydration capacity and viscosity. The results indicate that indepen1dent variables (barrel temperature, feed composition and feed moisture content) significantly $(p<0.05)$ affected the functional property of the extrudate the optimal conditions of the variables were also ascertained. The result from this study could be used to explore the possibility by interested processors for effective prediction of a known process conditions for the purpose of achieving desired product quality.

\section{REFFERENCE}

Abaejoh R, Djomdi I, Ndojouenkeu R(2006). Characteristics of tiger nut (Cyprus esculentus) tubers and their performance in the production of a milky drink. J. Food Process. Preserve, 30: 145-163.

Abdulrahman AA, Kolawole OM(2003). Traditional preparation and uses of maize in Nigeria. African J. Biotechnol., 4: (3) 1-5.

Ade-Omowaye, B.I.O., Akinwande, B.A., Bolarinwa, I.F. and Adebiyi, A.O. (2008). Evaluation of tiger nut (Cyprus esculentus) - wheat composite flour and bread. Afr. J Food Sci., 2: 87-91.

Anyasor GN, Ogunwenmo KO, Oyelana OA, Ajayi D, Dangana $\mathrm{J}(2009)$.Chemical Analyses of Groundnut(Arachi hypogaea) Oil. Pak. J. Nutri .8 (3):269-272.

Anderson RA, Conway HF, Pfeifer VF, Griffin EL(1969). Gelatinization of corn grits by roll and extrusion cooking. Cereal Science Today, 14, 4-12.

AOAC (2000). Association of Official Analytical Chemists. Official methods of Analysis of AOAC International. Washington, DC, USA. Official methods 923.03, 923.05, 925.09, 962.09, and 979.09

Asibuo JY, Akromah, R, Safo-Kantanka OO, Sei, Adu D, Hanskofi OS, Agyeman A(2008). Chemical Composition of Groundnut, Arachis hypogaea(L) landraces. African J. Biotechnol. Vol, 7(13), pp: 22032208.

Asiedu A, Lied E, Nilsen, R, Sandnes K (1993). Effect of processing (sprouting And/or fermentation) on sorghum and maize: II. Vitamins and amino acid compostion Biological utilization of maize protein. Food Chem. 48:201-204.

Bagirei SY(2005). Process optimization and storability of dakuwa: An indigeneous cereals/legume-based snack. Unpublished master's thesis, Department of food science and technology, university of Ibadan, Nigeria.

Bansal UK, Satija, DR, Ahula KL(1993).Oil Composition of diverse groundnut (Arachi hypogaea.L) genotypes relation to different environments. J. Sci. Food Agric.63:17-19.Belewu MA, Abodurin $\mathrm{AO}(2006)$. Preparation of Kunu from unexploited rich food sourcetiger nut (Cyperus esculentus). Pak. J. Nutr. 7:109-111. Belewu

MA, Belewu KY(2007). Comparative physiochemical evaluation of tiger nut, soybean and coconut milk sources. Int. J. Agric. Biol. 5:785-787.

Beta T, Rooney LW, Marovatsanga LT, Taylor JRN(1999). Phenolic compounds and kernel characteristics of Zimbabwean Sorghums. J. Sci. Food Agric., 79, pp 1003-1010.

Bhattachyra M, Hanna MA (1986). Textrural properties of extruded plant protein Journal of Food Science, 487-499. 
BSTID-NRC. (1996). Board on Science and Technology for International Development-National Research Council. Lost crops of Africa. Academic Press, Washington DC, pp. 127-213.

Colonna P, Mercier C(1983). Macromolecular Modifications of Manioc Starch Components by Extrusion-Cooking with and without Lipids. Carbohydrate Polymers, 3, 87-108.

Dicko MH, Gruppen H, Traore AS, Van Berkel WJH, Voragen AGJ(2005). Evaluation of the effect of germination on phenolic compounds and antioxidant activities in sorghum varieties. J. Agri. And Food Chem., 53, pp 2581-2588.

Ding QB, Ainsworth P, Plunkett A, Marson $\mathrm{H}(2006)$. The effects of extrusion conditions on the functional and physical properties of wheat-based expanded snacks. J. Food Engineering, 73, 142-148.

Dowling LF, Arndt C, Hamker BR(2002). Economic viability of high digestibility sorghum as food for market broiler. Agronomy J. 94, pp 1050-1058.

Ebadi MRJ, Pourreza J, Jamalia MA, Edris AH, Mirhadi SA(2005). Amino acid content and availability in low, medium and high tannin sorghum in grain for poultry. Int. J. Poult. Sci., 1, pp 27-31.

Gassem M(1999). Study of the micro-organisms associated with the fermented bread (khamir) produced from sorghum in Gi- zan region, Saudi Arabia.

Gaydon EM, Bianchini JP, Ratovogery J(1983). Triter pene alcohols, methyl sterols, and fatty acid five Malagasy legume seed oils. J. Agric Food Chem., 31: 833-836.

Genstat (2013).Version 16 of Gen stat for windows. Statistical Package for Biometrics

Grosso NR, Guzman CA(1995).Chemical Composition of Aboriginal Peanut (Arachi hypogaea.L) Seeds from Peru. J.Agric.Food Chem.43:102-105.

Grosso NR, Lucini El, Lopez AG, Guzman CA(1999).Chemical Composition of Aboriginal Peanut (Arachi hy1pogaea.L) Seeds from Uruguay. Grasasy Aceites, 50:203-207.

Grosso NR, Zygadlo J A, Lamarque AL, Maestri DM, Guzman CA (1997).Proximate, Fatty acid and sterol Compositions of Aboriginal Peanut (Arachi hypogaea.L) Seeds from Bolivia. J.Sci.Food Agric.73:249-356.

Gujska E, Khan K(1991). Feed moisture effects on functional properties, tripsin inhibitors and hemaglutinating activities of extruded bean high starch fractions. J. Food Sci. 56:443-447.

Hagenimana A, Ding X, Fang(2006). Evaluation of rice flour modified by extrusion cooking. J. cereal sci., (43) 38-45.

Harper J, Jansen $\mathrm{G}(1985)$. Production of nutritious precooked foods in developing countries by low-cost extrusion technology. Food Rev. Int. 1, 27-97.

Hettiarachchy NS, Kalapathy U(1998). Functional properties of soy proteins and lipids. ACS symposium series Washington, DC:American Chemical Society, 708, Pp80-95.

Jager T, Van Zuilichem DJ, Stolp W(1992). Residence Time Distribution, Mass Flow, and Mixing in a Co-Rotating Twin- Screw Extruder, in Food Extrusion Science Technology, Marcel Dekker, ed. New York, pp 71-88.

Jambunathan R, Merz ET, Axtell JD(1975). Fractionation of soluble proteins of high lysine and normal sorghum grain.J Cereal Chem., 52: 119-121.

Kofi ME(1990). Local packaging of food in Ghana. Food and Nutrition bulletin, 12:1, published by the United Nations University, Tokyo Japan, pp: 15

Kordyias JM(1990). Processing and preservation tropical and subtropical food. J. Agric. Food Technol., 12: 28-40.

Laike K(2006). Effect of extrusion operating conditions on the physicochemical and sensory properties of grain tef puffed product. Msc thesis, Haramaya University. Mason D(2008). Tiger-nuts, National vegetable society. http: /www.nvsuk.org uk/growing_show_vegetables 1/ Tiger-nut. Ph.D.

Montgomery DC(1997), Design and Analysis of Experiments, 4th edition, John Wiley \& Sons, New York. (1st edition)

Nkama I, Gbenyi DI(2001). The effect of malting of millet and sorghum on the residual phytates and polyphenols in Dakuwa - a Nigerian cereal-legume snack food, Nigerian J. Tropical Agriculture, 3: 270275.
Oladele AK, Aino JO(2007). Chemical composition and functional properties of flour produced from two varieties of tiger nut (Cyperus esculentus). Afri. J. Biotechnol., 6:2473-2476.

Omode A, Fatoki O, Olaogun KA(1995). Physico- chemical properties of some under exploited and non-conventional oil seed. J. Agric. Food Chem., 11: 50-53.

Oyango C, Henle T, Zeims A, Hoffman T, Belly T(2004). Effect of extrusion variables 1 on fermented maize-finger millet blend in the production of uji. LWT, 37, 409-415.1

Onyeka U, Dibia I(2002). Malted we1aning food made from maize, soybean, groundnut and banana. J sci. Food and Agric. 82 (5): 3438.

Pansawat JK, Jangchud A, Wuttijumno1ng P, Saalia FK, Eitenmiller RR, Philips RD(2008). Effects of extrusion1 conditions on secondary extrusion variables and physical properties of fish, ricebased snacks. LWT, 41, 632-641.

Reyes-Moreno C, Milan-Carrillo J, Rouzaud-Sandez O, GarzonTiznado JA, Mora-Escobedo R(2002). Dehulling/Softening/Extrusion (DSE): Technological alternative to improve nutritional quality of Chickpea (Cicer arietinum L.) Rooney Sena-saldivar SO(1991). Hand book of Cereal Science and Technology. Mercel Dekker, eds, New York. Pp 233-270.

Rooney LW, Serna-Saldivar SO(1982). Sorghum. In Handbook of cereal science and technology (Eds) Lorenz, K.J. and Kulp, K. Marcel Dekker, Inc. New York, U.S.A.

Savage GP, Keenan JI(1994). The Composition and Nutritive Value of Groundnut Kernels. In: Smart J(ed). The Groundnut Crop: Scientific basis for improvement. London: Chapman and Hall, pp.173- 213.

Sumathi A, Ushakumari R, Malleshi NG(2007). Physicochemical characteristics, nutritional quality and shelf-life of peal millet based extrusion cooked supplementary foods. Intl J. food sci. and nutrition, 58(5), 350-362.

Temple VJ, Ojobe TO, Kapseu NM(1990). Chemical analysis of tiger nut (Cyperus esculenta). J. Sci. Food Agric., 50: 262-263.

Thomas DJ, Artwell WA(1997).Starches. Eagan press Hand book series. Minnessota U.S.A.

Tiger nuts Traders, (2009). Tigernuts/Chufas Tigernuts Traders, S.L. Available online. www.tigernuts.com. Accessed Sept 13, 2009.

Ukwuru MU, Omachona LJ, Onokah N(2008). Production and quality assessment of tiger nute (Cyperus esculentus) imitation milk during storage. J. Food Sci. Technol., 45: 180-182.

Umerie SC, Okafor EP, Uka AS(1997). Evaluation of the tubers and oil of Cyperus esculentus. Bioresour. Technol. 6: 171-17.

Wise $D(2009)$. The Tiger nut My Top Bait. Available online: http://www.carp.uk.net/articles/tigernuts/ tigernuts.htm Accessed: Sept 21, 2009.

Yousif N, El Tinay $A(2001)$. Effect of fermentation on sorghum protein fractions and in vitro protein digestibility. Plant Foods for Hum. Nut. 56: $175-182$.

Yusuf M, Filli KB, Umar I, Halilu M(2017). Effect of Extrusion variables on Physical properties and Acceptability of Dakuwa produced from blends of Sorghum (Sorghum bicolour L) Graundnut (Arachis hypogea L) and Tigernut (Cyperus esculentus). African J. Food Sci. and Technol. Vol 8(5) pp 138-149. 